Table IV からわかるように， 誤差 $\pm 2 \%$ 以内で定 量することができた.

終りに原稿の校閲と有益な御批判を睗わった東京大学 平野四蔵教授に厚く感謝致します。また，本研究の発表 を許可された会社に感謝致します。

\section{交献}

1) JIS M 8401.

2) J. Clinch, E. A. Simpson : Analyst, 82, 258 (1958).

3）上野景平：“キレート滴定法”, p. 169 (1956), (南江堂).

4) K. Y. Bril, S. Holzer, B. Réthy : Anal. Chem., 31, 1353 (1959).

5) G. Brunisholz, R. Cahen : Helv. Chim. Acta, 39, 324 (1956).

6) C. V. Banks, J. A. Thompson, J. W. Olaughlin : Anal. Chem., 30, 1792 (1958).

7) D. C. Stewart, D. Kato : ibid., 30, 164 (1958).

8）日本原子力研究所調查報告 No. 13 (1959). is
Rapid determination of rare earths by the titration with EDTA. Shigeru Katsumata (Research Dept. Asahi Electro-chemical Co.)

A method for the determination of rare earths in monazite sand by the titration with EDTA has been established. The investigation has been pointed to the selection of indicator and the effect of interfering ions.

Neothorin which has not been known as an indicator is superior to Eriochrome Black $\mathrm{T}$ in a point of less interference by diverse ions. $\mathrm{Th}$ more than $10 \%$ of rare earths and $\mathrm{Al}$ or $\mathrm{Fe}$ more than $5 \%$ of them interfere.

After the sample is decomposed by sulfuric acid, $\mathrm{Al}, \mathrm{Fe}$ and other interfering ions are separated by precipitating rare earths with oxalic acid. Th is separated by the extraction with TBP. Rare earths are determined by the titration with an EDTA standard solution using Neothorin as an indicator.

By this procedure, rare earths in monazite sand can be determined rapidly with good result.

(Received May 31, 1961)

\title{
金属チタン中の全イオウの定量法および チタンによるイオウ化合物の分解
}

\author{
小田 仲彬，久保 正二*
}

（I）金属チタン試料を塩酸で分解し，分解ガスの捕集夜(アンモ二ア性塩化カドミウム溶液)の沈殿

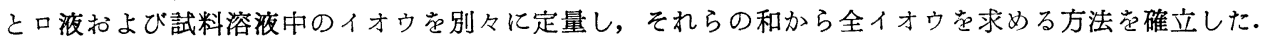
本法の添加実鍳の回収率は約 100\%，分析の精度は変動係数で約 10\%（S $0.003 \%$ 水準)，下限は $0.001 \%$ である.

(II) 前項の研究過程で, チタンの塩酸溶解の際に共存の亜硫酸塩が $\mathrm{H}_{2} \mathrm{~S}$ 亿, 硫酸塩が $\mathrm{H}_{2} \mathrm{~S}$ と $\mathrm{SO}_{2}$ にそれぞれ還元される現象をみとめたので，各種のイオウ化合物の還元に寄与するチタンの状態や還元 に関与する主なる因子の水準などにつき検討し，上記の現象を明確にした。な拉，てのイオウ化合物の 還元現象は金属チタンの特性であり，他の金属ではほとんぞおこらないてと，およびチタンを濃硫酸と 加熱すると $\mathrm{SO}_{2}$, 希硫酸と加熱すると $\mathrm{H}_{2} \mathrm{~S}$ 足生成するととをえれぞれ知見した。

\section{1 緒言}

金属チタンはその精練過程においてイオウを混入する 機会が多く, このものは他の非金属性不純元素と同様に その諸性質に悪影響をおよぼすことが考光られるので, 製品の品質および工程管理上金属チタン中のイオウの定 量が要望された。

* 日本曹達株式会社高岡工場：高岡市向野本町
金属チタン中のイオウの定量法としては，既に燃焙 法1)と湿式法23)について報ぜられているが，いずれも イオウが硫化物で存在するものと仮定している方法であ る. しかし，酸リーチやデスケーリングなどの処理を施 せる金属チタンには硫化物以外のイオウ化合物の存在も 考えられるので，著者らは金属チタン中の全イオウをそ の存在形態に関係なく定量する目的で, チタン中に硫化 物，西硫酸塩および硫酸塭として存在するそれぞれのイ 
オウの定量法にうき研究をおこなった. その結果, 試料 の塩酸分解ガスの捕集液（アンモニア性塩化カドミウム 溶液）の沈殿と口液および試料溶液のイオウを，それぞ れ求めることを骨子とする全イオウの定量法を明らかに した.

なお，金属チタン中のイオウ化合物の分別定量法に対 する本法の適用性についても検討し，捕集液の沈殿以外 にイオウ化合物をみとめない場合にはイオウは硫化物と して存在するものと推定されうるが，その他の場合には イオウ化合物の分別定量は困難であることをみとめた.

後者の主なる理由として, 金属チタンと共存のイオウ化 合物が㙉酸溶解の際に, チタンによって複雑な分解現象 をおこすことをみとめたのでそれらにつき検討し，その 機構や条件などをかなり明らかにすることができた。

\section{2 使用した材料および器具}

\section{$2 \cdot 1$ 試 料}

金属チタンは全チタン $99.5 \%$ の粉末チタン (300メッ シュ程度）を使用.

\section{$2 \cdot 2$ 試、薬}

アンモニア性塩化カドミウム溶液：結晶㙁化カドミウ ム $\left(\mathrm{CdCl}_{2} \cdot 2^{1} 1 / 2 \mathrm{H}_{2} \mathrm{O}\right) 55 \mathrm{~g}$ 觉水 $500 \mathrm{ml}$ にとかし, 濃 アンモニア水 $1200 \mathrm{~m} l$ 芭加光水で $2.5 l$ とする. 使用時 さらに水で倍量にうすめる。

$1 / 50 N$ ヨウ素溶液および $1 / 50 N$ チオ硫酸ナトリウム 溶液: : ヨウ素滴定に用いるヨウ素とチ才硫酸ナトリウム の濃度は従来 ${ }^{22} 1 / 20 N$ が採用されているが， $1 / 50 N$ で も明確な終点の判定がごるのので, 感度の見地から $1 / 50$ $N$ を用いるとととし，その調製扣よび標定は常法によっ た.

その他の試薬は断わりない限り特級品を用いた。

\section{$2 \cdot 3$ 器 具}

水素発生器, 試料溶解容器扣よび分解ガス捕集器には

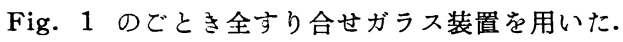

\section{3 金属チタン中の全イオウの定量条件の検討}

金属チタン中の全イオウの定量の見地から，従来の硫 化物のみを対象とする硫化水素発生法23) およびその硫 酸バリウム重量法4)との組合せにつき以下の実験をおこ なった。

\section{$3 \cdot 1$ 試料溶解}

従来, 金属チタン中のイオウの定量用の試料溶解剤は 塩酸に少量の塩化第一スズ2)またはフッ化水素酸》を加 えたものが用いられている．著者らはこの両者を比較し シ 結果, 後者は前者よりも溶解時間の点で有利であるが,

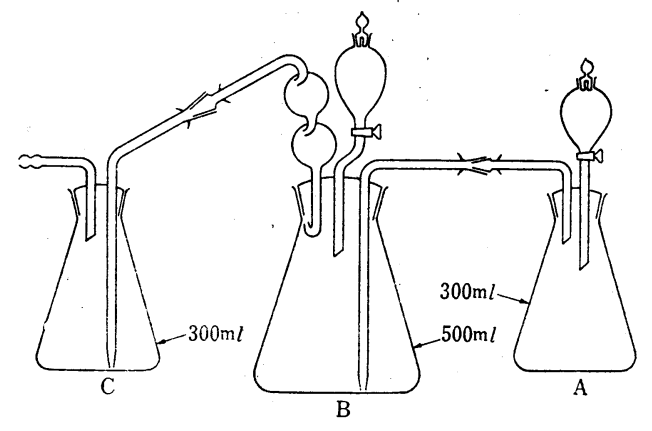

Fig. 1 Apparatus for determination of sulfur in the evolved-gas during the dissolution of titanium
A : $\mathrm{H}_{2}$ generator containing zinc and $\mathrm{HCl}(2+1)$
B : Sample dissolution vessel containing sample and $\mathrm{HCl}(2+1)$
C : Gas collector containing ammoniacal cadmium chloride solution

ガラス容器のふ食などの点では実用性にそしいことをみ とめた.しかし, 前者は塩酸単独による溶解に比べ溶解 時間や溶解状況などにおいて有利な点をほとんどみとめ えないので，塩酸のみによる溶解を採用した. 実験の結 果, 試料 $10 \mathrm{~g}$ に対し塩酸 $(2+1) 150 \mathrm{ml}$ を適当とみと めた.

このような塩酸のみによる溶解は，通常の工業用金属 チタンでは不溶残サを生ずることなく適当であることを みとめたが，特殊なチタン試料には適用できない場合が ある・たとえば，金属チタン利用の目的でおこなわれた 亜硫酸ガスによるふ食実験後のチタン試料5)の場合には 塩酸, フッ化水素酸のいずれを用いてもほとえど不溶で ある. 検討の結果, このような特殊試料の場合には, 試 料 $0.5 \mathrm{~g}$ に炭酸ナトリウムと過酸化ナトリウムの等量混 合融剂(8) $5 \mathrm{~g}$ を混和し, ニッケルルツボ中で融解後, 15 \%塩酸で浸出することにより試料は完全に溶解し, 溶液 中のイオウは後述(3・3) の方法で求められることをみと めた.

\section{$3 \cdot 2$ 塩酸分解ガス中のイオウの定量}

従来の硫化水素発生法では, 金属チタンを酸溶解した 際に生成する分解ガス中のイオウ化合物を硫化水素とみ なしてイオウを求めているが，イオウが種々の形態で存 在する場合には硫化水素以外に亜硫酸ガスの発生も考元 られる. それでアンモニア性塩化カドミウム溶液が硫化 水素によって硫化カドミウムの黄色沈殿を生ずるのに対 し, 亜硫酸ガスでは沈段を生成しないことに着目し, こ れらの金属チタンの酸分解ガス中の硫化水素と亜硫酸ガ 
スの分別定量への適用につき実験した.すなわち，金属 チタン $10 \mathrm{~g}$ に対し種々のイオウ化合物（硫化ナトリウ ム，亜硫酸ナトリウム，硫酸カリウム, 硫酸チタンなど） をそれぞれイオウとして $0.5 \mathrm{mg}, 1.0 \mathrm{mg}$ の 2 水準を水 溶液として共存せしめた各試料の塩酸分解ガスをアンモ ニア性塩化カドミウム溶液に捕集し，口過後，沈殿およ びロ液中のイオウをそれぞれヨウ素滴定で求めた。この 場合沈殿のイオウは硫化水素, 口液のそれは亜硫酸ガス にそれぞれよるものと考光られ，前者のイオウ量 $(\mathrm{mg})$ を $\mathrm{S}_{1}$, 後者のそれを $\mathrm{S}_{2}$ として結果の一例を示せば Table I のと扔りである.

Table I Sulfur recoveries on synthetic samples ${ }^{\dagger}$

\begin{tabular}{|c|c|c|c|c|c|c|}
\hline \multirow{2}{*}{$\begin{array}{l}\text { Substances } \\
\text { added }\end{array}$} & \multirow{2}{*}{$\begin{array}{l}\text { Sulfur } \\
\text { present } \\
(\mathrm{mg})\end{array}$} & \multicolumn{4}{|c|}{ Sulfur found (mg) } & \multirow{2}{*}{$\begin{array}{l}\text { Recovery of } \\
\text { total sulfur } \\
(\%)\end{array}$} \\
\hline & & $\mathrm{s}_{1}+\dagger$ & $\mathrm{S}_{2}+\dagger$ & $\mathrm{S}_{3} \mathrm{t \dagger}$ & T.S.t† & \\
\hline $\mathrm{Na}_{2} \mathrm{~S}$ & $\left\{\begin{array}{l}0.5 \\
1.0\end{array}\right.$ & $\begin{array}{l}0.461 \\
1.000\end{array}$ & $\overline{-}$ & $=$ & $\begin{array}{l}0.461 \\
1.000\end{array}$ & $\begin{array}{r}92.2 \\
100.0\end{array}$ \\
\hline $\mathrm{Na}_{2} \mathrm{SO}_{3}$ & $\left\{\begin{array}{l}0.5 \\
1.0\end{array}\right.$ & $\begin{array}{l}0.299 \\
0.650\end{array}$ & $\begin{array}{l}0.179 \\
0.346\end{array}$ & $\underline{-}$ & $\begin{array}{l}0.478 \\
0.996\end{array}$ & $\begin{array}{l}95.6 \\
99.6\end{array}$ \\
\hline $\mathrm{K}_{2} \mathrm{SO}_{4}$ & $\left\{\begin{array}{l}0.5 \\
1.0\end{array}\right.$ & $\begin{array}{l}0.158 \\
0.256\end{array}$ & $\begin{array}{l}0.041 \\
0.064\end{array}$ & $\begin{array}{l}0.266 \\
0.687\end{array}$ & $\begin{array}{l}0.465 \\
1.007\end{array}$ & $\begin{array}{r}93.0 \\
100.7\end{array}$ \\
\hline $\mathrm{Ti}\left(\mathrm{SO}_{4}\right)_{2}$ & $\left\{\begin{array}{l}0.5 \\
1.0\end{array}\right.$ & $\begin{array}{l}0.136 \\
0.187\end{array}$ & $\begin{array}{l}0.048 \\
0.056\end{array}$ & $\begin{array}{l}0.302 \\
0.707\end{array}$ & $\begin{array}{l}0.486 \\
0.950\end{array}$ & $\begin{array}{l}97.2 \\
95.0\end{array}$ \\
\hline
\end{tabular}

$\dagger$ Determinations were carried out on synthetic samples prepared by hydrochloric acid dissolution of mixtures containing each sulfur compound and $10 \mathrm{~g}$ of commercial pure titanium powder.

†† $\mathrm{S}_{1}$ : sulfur as $\mathrm{H}_{2} \mathrm{~S}, \mathrm{~S}_{2}$ : sulfur as $\mathrm{SO}_{2}, \mathrm{~S}_{3}$ : sulfur as sulfate, T.S. : total sulfur

Table I から硫化ナトリウムの場合に法硫化水素の みが生成され，イオウは $\mathrm{S}_{1}$ として約 100\% 回収される のに対し, 亜硫酸ナトリウムの場合には硫化水素と亜硫 酸ガスが生成され，イオウの回収率は $\mathrm{S}_{1}$ と $\mathrm{S}_{2}$ の和で約 100\%を示した. また硫酸カリウムと硫酸チタンの場合 には，それらのイオウの一部 (30～40\%) から硫化水素 と亜硫酸ガスが生成されていることをみとめた. 以上の 結果から, 分解ガス中の硫化水素と亜硫酸ガスはアンモ ニア性塩化カドミウム溶液により分別定量できることを みとめた. しかし，金属チタンと共存する硫化物以外の イオウ化合物の酸分解は後述 $(5 \cdot 1)$ のようにかなり複雑 であることから，その分解ガスで分別定量される $\mathrm{S}_{1}$ と $\mathrm{S}_{2}$ から原試料中におけるイオウ化合物の形態の判定ま たは分別定量は困難のようである. しかし， $\mathrm{S}_{1}$ しかみ とめない場合には $\mathrm{S}_{1}$ から原試料中の硫化物を定量する ことができる.

\section{$3 \cdot 3$ 塩酸溶液中のイオウの定量}

金属チタンを塩酸溶解した場合，溶液に残存するイ
オウはその溶解過程から，ほとえど 硫酸塩の形態をと るものと推定されるが， $\mathrm{SO}_{4}{ }^{2-}$ の一部 $(<0.1 \%)$ と $\mathrm{Ti}^{4+}$ から硫酸バリウムの沈殿を生成しにくい錯イオン $\left\{\left[\mathrm{Ti}\left(\mathrm{SO}_{4}\right)_{3}\right]^{2-}\right\}$ を形成することがしられている3． そ れでチタン共存下における硫酸塩を定量的に硫酸バリウ ムにかえるには，あらかじめチタンの除去を要するもの と考元，金属チタンの塩酸溶液を硝酸で酸化したのち， 四塩化チタンてでおこなわれているようにアンモニア水 でチタンをあらかじめ除去する方法につき実験した。す なわち，硫酸塩を添加した金属チタン試料（Table I) の䜖酸溶液を用い, 後述 $(4 \cdot 2)$ のように, チタンをあら かじめアンモニア水で水酸化チタンにして除去した溶液 中のイオウ量 $(\mathrm{mg})\left(\mathrm{S}_{3}\right)$ を硫酸バリウム重量法で求めた (Table I).

Table I から硫酸塩の場合には，そのイオウの一部 から硫化水素と亜硫酸ガスが生成し塩酸分解ガス中へ移 行することがわかる。したがって，上述の方法では金属 チタン中の硫酸塩の分別定量は困難であるものと考元ら れる。しか，金属チタンに硫酸塭が共存する場合，そ の塩酸分解ガスと塩酸溶液中のイオウ量の和 $\left(\mathrm{S}_{1}+\mathrm{S}_{2}+\right.$ $\mathrm{S}_{3}$ ）が約 100\% の回収率を示严ことから，金属チタン中 の全イオウの定量には試料の塩酸溶液中のイオウをも定 量することが必要であること，およびこの溶液中のイオ ウは上述のように，チタンをあらかじめ分離することに より硫酸バリウム重量法が適用できることをみとめた。

Table I の添加実験結果から金属チタンと共存する 硫化物，亜硫酸塩および硫酸塩のおのおのの全イオウは $\mathrm{S}_{1}, \mathrm{~S}_{2}, \mathrm{~S}_{3}$ の合量で求められることがわかったが，本実 験でとりあげなかった他の形態のイオウ化合物の全イオ ウも, 本法の $\mathrm{S}_{1}, \mathrm{~S}_{2}, \mathrm{~S}_{3}$ の和で求めうるものと考光ら れるので，金属チタン中の全イオウは 3.2 と 3.3 を組み 合わせることにより定量できるものと考える。

\section{4 本法による金属チタン中の 全イオウの定量法}

以上の研究成果を総合して得た金属チタン中の全イオ ウの定量法は次のごとくである.

\section{$4 \cdot 1$ 操 作}

水素発生器 [Fig. 1(A)] 飞純金属亜鉛の切屑約 $50 \mathrm{~g}$ 々水 $30 \mathrm{~m} l$, 分解容器 [Fig. 1 (B)] に試料* $10 \mathrm{~g}$, 分

* 供試料よりの試料採取は粉末チタンの場合は縮分, スポンジタンの場合はコンパタトードリリング,金 属板あるいは塊はドリリングまたは旋盤切履などに よりそれぞれ扣こなう。 
解ガス捕集器 [Fig. 1(C)] にアンモニア性塩化カドミ ウム溶液 $100 \mathrm{ml}$ をそれぞれ入机，装置全体を Fig. 1 のごとく連結する．水素ガスが毎秒 1 気泡ずつ発生する ように Fig. 1(A) の分液ロートから塩酸 $(1+2)$ を滴 下しつつ, Fig. 1 (B) の分液ロートから塩酸 $(2+1)$ $150 \mathrm{ml}$ を添加する. のち Fig. 1(B) のフラスコを徐々 に加熱し, 試料が水素を発生しはじめたら Fig. 1 (A) の塩酸滴下をやめる. 試料が完全にとけたのち，ふたた び Fig. 1(A) より塩酸を前と同様に滴下しながら内容 物を 5 分間沸騰させる（不溶物をみとめた場合には口別 し, $3 \cdot 1$ に記載の炭酸ナトリウムと過酸化ナトリウムの 混合融剤で融解し, その溶解液を主液に合する). のち Fig. 1 (C) をとりはずして連結管を水洗し, 捕集液を No. 5C のロ紙を用いてロ過する*. 沈殿をアンモニア 水 $(1+50)$ で洗浄し, 沈殿（口紙共）およびロ液のおの おのに $1 / 50 N$ ヨウ素溶液 $10 \mathrm{ml}$ を加え, 塩酸 $(1+1)$ で酸性となし, 冷後 $0.25 \%$ デンプン溶液 $5 \mathrm{ml}$ を加え, $1 / 50 N$ チオ硫酸ナトリウム溶液でそれぞれ 青紫色の消 失する点まで滴定する.沈殿およびロ液に消費した $1 / 50$ $N$ チ才硫酸ナトリウム溶液の $\mathrm{ml}$ 数をそれぞれ $\mathrm{A}, \mathrm{B}$, 空試験のそれらを $\mathrm{C}, \mathrm{D}$ とすると $\mathrm{S}_{1} \%$ および $\mathrm{S}_{2} \%$ は 次式によって求められる.

$$
\begin{aligned}
& \mathrm{S}_{1} \%=\frac{(\mathrm{C}-\mathrm{A}) \times F_{1} \times 0.032}{\text { 試料量 }(\mathrm{g})} \\
& \mathrm{S}_{2} \%=\frac{(\mathrm{D}-\mathrm{B}) \times F_{1} \times 0.032}{\text { 試料量 }(\mathrm{g})}
\end{aligned}
$$

$F_{1}$ は $1 / 50 N$ チオ硫酸ナトリウム溶液の力価を示す. つぎに試料の塩酸溶液に濃硝酸 $40 \mathrm{~m} l$ を徐々に加え, 全量を約 $100 \mathrm{~m} l$ まで濃縮する. 水で $150 \mathrm{~m} l$ に希釈し, アンモニア水 $(1+1)$ でアルカリ性にして 5 分間沸騰さ せ，冷後内容物を遠心分離 $(3000 \mathrm{rpm}, 250 \mathrm{ml}$ カップ) し，上澄液をこしわける．沈殿に水を加えてよく混和し ふたたび遠心分離する. 2 回の上澄液を合し水酸化ナト リウム $2 \sim 3$ 粒を加え， ほとえど乾固するまで加熱す る.つぎに濃塩酸 $10 \mathrm{ml}$ を加えて蒸発乾固をおこなう. この操作を硝酸ガスが発生しなくなるまでくりかえす. のち乾固物を水にとかし，アンモニア水 $(1+1)$ でアル カリ性としてロ過する. 口液を水で約 $200 \mathrm{ml}$ とし, つ いで塩酸 $(1+1)$ で中和し, 更にその $2 \mathrm{ml}$ を過剩に加 えて加熱する・ほとえど沸騰しはじめたら，かきまぜな

* 本法では $\mathrm{S}_{1}, \mathrm{~S}_{2}, \mathrm{~S}_{3}$ の中 $\mathrm{S}_{1}$ しか検出されない場合 には，原試料中のイオウは硫化物として存在するこ とが推定されるが，もし全イオウのみを目的とする 場合には直ちに捕集液を塩酸で酸性となし、ヨウ素 滴定により $\mathrm{S}_{1}$ と $\mathrm{S}_{2}$ の合量を求めることができる.
がら $10 \%$ 塩化バリウム溶液 $10 \mathrm{ml}$ を滴下し, 沸騰水浴 上で数時間加熱後一夜放置し，No. 5C の口紙を用いて 口過する.ビーカーの底部に固着した沈殿を清浄な筆で 落したのち口紙上の沈殿を温湯で洗浄し, 以下常法どお りに沈殿を強熱して硫酸バリウムの重量（A g ）を求め る. 同様にして空試験の硫酸バリウムの重量（B g ）を 求め, 次式によって $\mathrm{S}_{3} \%$ を算出する.

$$
\mathrm{S}_{3} \%=\frac{(\mathrm{A}-\mathrm{B}) \times 13.7}{\text { 試料量 }(\mathrm{g})}
$$

$\mathrm{S}_{1}, \mathrm{~S}_{2}, \mathrm{~S}_{3}(\%)$ の和を全イオウ \% とする.

\section{$4 \cdot 2$ 本法の実用性}

本法による分析精度の一例を, スポンジチタンおよび 粉末チタンの各 7 回くりかえしの分析結果から求めた変 動係数 $(\sigma \%)$ で示せば，S $0.003 \%$ 水準で約 $10 \%$ で ある. また, Table I のごとく金属チタンに硫化ナト リウム, 亜硫酸ナトリウム, 硫酸カリウム拉よび硫酸チ タンの各既知量を単独に添加した場合のイオウの回収率 がいずれも約 100\%を示すことから，本法の正確度はか なり满足できるものと思われる.つぎに本法で求めた工 業用スポンジチタン (20〜30メッシュ) 扎よび粉末チタ ン (300メッシュ以下) 中のイオウ\%の一例を, Table II に示す.

Table II Analytical results

\begin{tabular}{llllll}
\hline \multirow{2}{*}{ Sample } & \multicolumn{4}{c}{ Sulfur (\%) } \\
\cline { 3 - 5 } Titanium sponge & & $\mathrm{S}_{\mathrm{S}_{1}}$ & $\mathrm{~S}_{2}$ & $\mathrm{~S}_{3}$ & T.S. \\
Titanium powder & $\mathbf{0 . 0 0 3 2}$ & - & - & 0.0032 \\
$\mathrm{~B}$ & 0.0026 & - & - & 0.0026 \\
$\mathrm{~B}$ & 0.0024 & - & - & 0.0024 \\
& & 0.0021 & - & 0.0012 & 0.0033 \\
\hline
\end{tabular}

Table II より通常の工業用スポンジチタン中のイオ ウは硫化物として存在し, 酸リーチ粉末チタンではイオ ウは硫化物のほかに硫酸塩としても存在していることが わかる.なお，同表で $\mathrm{S}_{2}$ がみられないのはその含量が 感度以下になっていることによるものと思う。

つぎに本法の定量下限は約 $0.001 \%$ と推定され，分析 所要時間は 1 試料につき $S_{1}$ と $S_{2}$ で約 3 時間, $S_{1}, S_{2}$ お よび $\mathrm{S}_{3}$ で約 12 時間（硫酸バリウムの一夜放置を含ま ず）である.

\section{5 チタンによるイオウ化合物の 分解現象の検討}

金属チタンの塩酸溶液に際し, 共存の亜硫酸塩の全部 および硫酸塩の一部分からそれぞれ前述(3・2) のように 
硫化水素と亜硫酸ガスが生成される現象は従来しられて いないようである.それでそれらの生成の機構や条件な どにつき若干の検討をこころみた。 また，金属チタンに みられるこのような現象が従来還元剤として使われてい る他の金属においても，おこるかどうかなどについても 実験した.

\section{$5 \cdot 1$ 分解機構}

前述 $(3 \cdot 2)$ のように, 亜硫酸塩または硫酸塩を共存す る金属チタンを塩酸溶解すると硫化水素と亜硫酸ガスが 生成するの注，亜硫酸塩から生成される亜硫酸ガスを除 けば明らかにそれらのイオウがチタンによって還元され ていることを示すので，これらのイオウ化合物の還元に 寄与するチタンの状態を明らかにするため以下の実験を こころ多た。すなわち，Fig. 1 の装置を用いて前述 $(4 \cdot 2)$ 乙同様な条件で，イオウとして $1 \mathrm{mg}$ に相当する 亜硫酸ナトリウムまたは硫酸カリウムの水溶液を，（I） 塩酸 $(2+1) 150 \mathrm{~m} l$ に添加して加熱, (II) 䘏酸 $(2+1)$ $150 \mathrm{~m} l$ で加熱溶解した直後の金属チタン $(10 \mathrm{~g})$ 溶液に 添加，(III) 金属チタン $(10 \mathrm{~g})$ に添加したのち塩酸 $(2+$ 1) $150 \mathrm{ml}$ で加熱溶解，のおのおのにつき生成する酸分 解ガス中の硫化水素と亜硫酸ガスに対するイオウ $\mathrm{S}_{1}$, $\mathrm{S}_{2}$ をそれぞれ前述 (4・2) の定量法によって求めた. 結 果は Table III のとおりである.

Table III Conditions of titanium dissolution and the efficiency of the reduction of sulfite or sulfate

\begin{tabular}{|c|c|c|c|}
\hline \multirow{2}{*}{ Conditions of dissolution } & \multirow{2}{*}{$\begin{array}{l}\text { Sulfur } \\
\text { compound } \\
\text { added } \dagger\end{array}$} & \multicolumn{2}{|c|}{$\begin{array}{l}\text { Sulfur } \\
\text { recovered }(\mathrm{mg})\end{array}$} \\
\hline & & $\mathrm{S}_{1}$ & $\mathrm{~S}_{2}$ \\
\hline $\begin{array}{l}\text { (I) The sulfur compound only } \\
\text { was dissolved into } \mathrm{HCl}(2+1) \\
150 \mathrm{ml}\end{array}$ & $\begin{array}{l}\mathrm{Na}_{2} \mathrm{SO}_{3} \\
\mathrm{~K}_{2} \mathrm{SO}_{4}\end{array}$ & - & $\begin{array}{c}0.98 \\
-\end{array}$ \\
\hline $\begin{array}{l}\text { (II) The sulfur compound was } \\
\text { added after } \mathrm{Ti}(10 \mathrm{~g}) \text { had been } \\
\text { dissolved in } \mathrm{HCl}(2+1) 150 \mathrm{ml}\end{array}$ & $\begin{array}{l}\mathrm{Na}_{2} \mathrm{SO}_{3} \\
\mathrm{~K}_{2} \mathrm{SO}_{4}\end{array}$ & 0.71 & $\begin{array}{c}0.27 \\
-\end{array}$ \\
\hline $\begin{array}{l}\text { (III) The sulfur compound was } \\
\text { added before } \mathrm{Ti}(10 \mathrm{~g}) \text { was } \\
\text { dissolved in } \mathrm{HCl}(2+1) .150 \mathrm{ml}\end{array}$ & $\begin{array}{l}\mathrm{Na}_{2} \mathrm{SO}_{3} \\
\mathrm{~K}_{2} \mathrm{SO}_{4}\end{array}$ & $\begin{array}{l}0.68 \\
0.19\end{array}$ & $\begin{array}{l}0.31 \\
0.06\end{array}$ \\
\hline
\end{tabular}

Table III より，（I）のようにチタンを共存しない 場合には酸を加えても硫酸カリウムは分解しないし，覀 硫酸ナトリウムも単に亜硫酸ガスを定量的に生成するこ とから, 硫酸カリウムや亜硫酸ナトリウムのイオウは酸 単独では還元をうけないことがわかる，つぎに (II) の ように金属チタンを水素気流中で塩酸溶解し, $\mathrm{Ti}^{3+}$ と したのちイオウ化合物を添加した場合には硫酸カリウム
は（I）と同様に分解しないが，亜硫酸ナトリウムから 硫化水素亡 亜硫酸ガスを生成している.このことから $\mathrm{Ti}^{3+}$ は硫酸を還元しないが，亜硫酸塩(亜硫酸ガス) は 硫化水素に還元されることがわかるまた，(III）のよ うに金属チタンの塩酸溶解前から共存する硫酸カリウム は硫化水素と亜硫酸ガスをとれぞれ生成することから， 硫酸塩が亜硫酸塩（亜硫酸ガス）に還元されるのは，金 属チタンが $\mathrm{Ti}^{3}+$ になる過程においておこなわれるもの と考えられる.

以上の結果に対し亜硫酸塩と硫酸塩の還元の難易性を 考慮に入れると，金属チタンと共存する亜硫酸㙉または 硫酸塩が酸溶解において, 硫化水素と亜硫酸ガスを生成 することに寄与するチタンの状態は次のように推定され る.すなわち，いずれの場合も金属チタンが、 $\mathrm{Ti}^{4+}$ に至 る過程のある領域であるが，硫酸塩の場合には特に金属 $\mathrm{Ti}$ が $\mathrm{Ti}^{3+}$ になる過程の状態が必要である.

つぎに上述のような現象がチタン以外の金属において もおこるかどうかを確かめるために，Table IV に示す 各種の還元用金属の各 $5 \mathrm{~g}$ にイオウ $100 \mathrm{mg}$ に相当する 硫酸カリウム溶液をそれぞれ共存させたものを塩酸（金 属ジルコニウムのみは塩酸とフッ化水素酸）で完全に加 熱溶解し, 既述 $(4 \cdot 2)$ のようにして求めた $\mathrm{S}_{1}, \mathrm{~S}_{2}$ の合 量からイオウの分解率を求めた (Table IV).

Table IV Decomposition ratio(\%) $\dagger$ of potassium sulfatett coexisting with various metals $t \dagger$

\begin{tabular}{llc}
\hline \hline Metal & Acid for dissolution & $\begin{array}{c}\text { Decomposition } \\
\text { ratio (\%) }\end{array}$ \\
\hline $\mathrm{Ti}$ & $\mathrm{HCl}(1+1) 200 \mathrm{~m} l$ & 2.0 \\
$\mathrm{Zr}$ & $\mathrm{HCl}(1+1) 100 \mathrm{~m} l+\mathrm{HF}(1+4) 50 \mathrm{ml}$ & - \\
$\mathrm{Mg}$ & $\mathrm{HCl}(1+2) 150 \mathrm{~m} l$ & - \\
$\mathrm{Zn}$ & $\mathrm{HCl}(1+1) 200 \mathrm{ml}$ & - \\
$\mathrm{Al}$ & $\mathrm{HCl}(1+1) 200 \mathrm{ml}$ & - \\
$\mathrm{Sn}$ & $\mathrm{HCl}($ Conc.) $200 \mathrm{ml}$ & 0.1 \\
$\mathrm{Cr}$ & $\mathrm{HCl}(1+1) 200 \mathrm{ml}$ & - \\
$\mathrm{Fe}$ & $\mathrm{HCl}(\mathrm{I}+1) 200 \mathrm{~m} l$ & - \\
$\mathrm{Mn}$ & $\mathrm{HCl}(1+2) 150 \mathrm{ml}$ & - \\
\hline
\end{tabular}

$\dagger\left(S_{1}+S_{2}\right) /$ sulfur added $\times 100$

t† $5 \mathrm{~g}$ of metal were mixed with potassium sulfate corresponding to $100 \mathrm{mg}$ of sulfur in each experiment.

Table IV から明らかなように, 金属チタン以外の金 属はいずれもほとんど分解しないことを示した。したが って, 金属と共存の硫酸塭の一部分が酸溶解の際に, 硫 化水素と亜硫酸ガスに還元されるのはチタンの特性であ るといえよう:

\section{$5 \cdot 2$ 分解条件}

前項から亜硫酸塩や硫酸塩を共存させ金属チタンを塩 
酸で溶解する際には，通常の金属（鉄，マグネシウムな ど）と共存する場合よりも還元過程の進行したイオウ化 合物を生成することを推定した. それで更に分解機構の 複雑な硫酸塩につき，チタンによるその硫化水素と亜硫 酸ガスへの分解率（\%）と溶解に関する主なる因子との 関係の概略を推定するためにつぎの実験をおこなった。 すなわち, 金属チタン, 濃塭酸, 水および硫酸カリウム の各量をそれぞれ Table V の 3 水準にえらび, 2 回く りかえしの $(3 \times 3)$ グレコラテン方格で実験をおこない， Table VIのごとき分解率（添加イオウ量に対する硫化 水素と亜硫酸ガス中のイオウ合量を\%で表示）をえた.

Table V Source of variation and level of conditions in $(3 \times 3)$ Graeco-Latin square experiment

\begin{tabular}{llllllll}
\hline \hline Source of variation & \multicolumn{5}{c}{ Level of conditions } \\
\hline A) Quantity of titanium powder $(\mathrm{g})$ & $\mathrm{A}_{1}$ & 3 & $\mathrm{~A}_{2}$ & 5 & $\mathrm{~A}_{3}$ & 10 \\
B) Quantity of sulfur in $\mathrm{K}_{2} \mathrm{SO}_{4}$ & $\mathrm{~B}_{1}$ & 1 & $\mathrm{~B}_{2}$ & 10 & $\mathrm{~B}_{3}$ & 100 \\
solution (mg) & $\mathrm{C}_{1}$ & 100 & $\mathrm{C}_{2}$ & 150 & $\mathrm{C}_{3}$ & 200 \\
C) Quantity of conc. $\mathrm{HCl}(\mathrm{m} l)$ & $\mathrm{D}_{1}$ & 0 & $\mathrm{D}_{2}$ & 50 & $\mathrm{D}_{3}$ & 100 \\
D) Quantity of $\mathrm{H}_{2} \mathrm{O}(\mathrm{ml})$ & & & &
\end{tabular}

Table VI Decomposition ratio (\%) of potassium sulfate coexisting with titanium in the $(3 \times 3)$ Graeco-Latin square experiment

\begin{tabular}{lllllllll}
\hline \multicolumn{1}{c}{$\mathrm{A}_{1}$} & $\overbrace{\mathrm{C}_{1}}^{c} \mathrm{C}_{2} \mathrm{D}_{1}$ & $5.8,8.4$ & $\mathrm{C}_{2} \mathrm{D}_{2}$ & 25.2, & 29.4 & $\mathrm{C}_{3} \mathrm{D}_{3}$ & $17.0,15.3$ \\
$\mathrm{~B}_{2}$ & $\mathrm{C}_{2} \mathrm{D}_{3}$ & $4.3,3.7$ & $\mathrm{C}_{3} \mathrm{D}_{1}$ & 2.6, & 2.7 & $\mathrm{C}_{1} \mathrm{D}_{2}$ & $10.7,12.0$ \\
$\mathrm{~B}_{3}$ & $\mathrm{C}_{3} \mathrm{D}_{2}$ & $0.8,0.8$ & $\mathrm{C}_{1} \mathrm{D}_{3}$ & 2.7, & 2.7 & $\mathrm{C}_{2} \mathrm{D}_{1}$ & 1.8, & 1.8 \\
\hline
\end{tabular}

Table VI の結果を分散分析すると，とりあげた因 子はいずれも分解率に対して有意となったので, 各因子 の各水準に打ける分解率を算出した. その結果から, Table V の 4 因子の組合せのなかで最高の分解率（約 30\%）を示す各因子と水準は，イオウとして $1 \mathrm{mg}$ に相 当する硫酸カリウムを共存させた場合, 金属チタン $5 \mathrm{~g}$, 濃塩酸 $150 \mathrm{ml}$, 水 $50 \mathrm{~m} l$ であることを知見した。

\section{$5 \cdot 3$ チタンによる硫酸の分解}

硫酸塩にみられた上述のチタンの還元作用が硫酸にお いてもおこるかごうかを確かめるために，Table VII に示す硫酸の濃度および量の各水準において金属チタン を共存させて加熱し，それぞれの分解ガス中の硫化水素 と亜硫酸ガスに対するイオウを前述 $(4 \cdot 2)$ と同様に $\mathrm{S}_{1}$, $\mathrm{S}_{2}$ として求めた（Table VII).
Table VII Decomposition of sulfuric acid by titanium $\dagger$

\begin{tabular}{lcccc}
\hline \hline $\begin{array}{c}\text { Concentration } \\
\text { of } \mathrm{H}_{2} \mathrm{SO}_{4}\end{array}$ & $\begin{array}{c}\text { Quantity } \\
\text { of } \begin{array}{c}\mathrm{H}_{2} \mathrm{SO}_{4} \\
(\mathrm{ml})\end{array}\end{array}$ & \multicolumn{3}{c}{ Sulfur found } \\
\cline { 4 - 6 } & $\mathrm{S}_{1}$ & $\mathrm{~S}_{2}$ & Remarks \\
\hline $\mathrm{H}_{2} \mathrm{SO}_{4}$ (conc.) & 100 & - & 2.6 & slightly dissolved \\
$\mathrm{H}_{2} \mathrm{SO}_{4}(100+1)$ & 100 & 0.3 & 1.3 & " \\
$\mathrm{H}_{2} \mathrm{SO}_{4}(1+4)$ & 250 & 103 & - & completely dissolved \\
\hline
\end{tabular}

$\dagger 10 \mathrm{~g}$ of titanium powder were used in each case.

Table VII からチタンの共存により濃硫酸の場合に は亜硫酸ガス, 希硫酸の場合には硫化水素をそれぞれ生 成することを知見した. 後者の結果は金属チタンを硫酸 で溶解する際に，若干の硫化水素を生成することを定性 的に指摘された既往の記述 ${ }^{3)}$ と一致する.

終りに本研究に対し種々御討議下さいました東京大学 平野四蔵教授, 東北大学後藤秀弘教授ならびに終始御鞭 撻を睗わりました日本曹達株式会社社長大和田悌二氏を 始め上司各位に対し䜕んで敬意を表する．また実験に協 力された山岸忠彦君に感謝する.

(昭和 32 年 4 月, 電気化学協会年会にて講演)

\section{交献}

1) M. Codell et al. : Anal. Chem., 29, 1496 (1957).

2) P. R. Perry et al. : "Method for Analyzing Titanium Sponge and Intermediated Products", U. S. Bur. Mines Rept. Invest. No. 5168, 12 (1955).

3) M. Codell : "Analytical Chemistry of Titanium Metals and Compounds", p. 280 (1959), (Interscience Publ. Inc., New York).

4) W. H. Treadwell : "Analytical Chemistry", Vol. 2, p. 393 (1951), (John Willey \& Sons, New York).

5) 武井 武, 平山和夫 : チタニウム, No. 53, 231 (1957).

6) W. Fresenius, G. Janđer : "Handbuch der Analytischen Chemie', Teil III, Bd. IV b, 15 (1950), (Springer Verlag, Ger.).

7) M. Codell : "Analytical Chemistry of Titanium Metals and Compounds", p. 293 (1959), (Interscience Publ. Inc., New York).

$$
\text { is }
$$

Determination of total sulfur in titanium metal and decomposition of sulfur compounds by titanium. Nakaaki OdA and Masaji Kubo (Nippon Soda Company Ltd., Takaoka Plant)

(I) A method for determination of total $\mathrm{S}$ in titanium metal has been presented as follows : The sample was decomposed with hydrochloric acid $(2: 1)$, the evolved gaseous product was. introduced in ammoniac cadmium chloride solution, and the resulted precipitate was filtered. The $S$ as sulfide $\left(S_{1}\right)$ from the precipitate and 
the $S$ as sulfite $\left(S_{2}\right)$ from the filtrate, respectively, were determined by iodometric titration. The remaining hydrochloric acid solution of the sample was oxidized with nitric acid, $\mathrm{Ti}$ was separated by precipitation with aqueous ammonia and the $S$ as sulfate $\left(S_{3}\right)$ was determined by the usual $\mathrm{BaSO}_{4}$ gravimetric method. The total $\mathrm{S}$ was calculated from the sum of $S_{1}, S_{2}$ and $S_{3}$. The recovery was almost $100 \%$ (Table I) with analytical precision in terms of coefficient of variation around $10 \%$ for $0.003 \% \mathrm{~S}$ in the metal, and the lower limit of determination was $0.001 \%$.

(II) In the preceding operations, reduction of sulfite or sulfate to $\mathrm{H}_{2} \mathrm{~S}$ or $\mathrm{SO}_{2}$ was observed in the dissolution of $\mathrm{Ti}$ with hydrochloric acid. The mechanism and the condition of the reduc- tion have been investigated, obtaining the following results : (1) Although the reduction of sulfite and sulfate was effectuated at the same region of conversion stage of metallic $\mathrm{Ti}$ to $\mathrm{Ti}^{4+}$, the conversion stage to $\mathrm{Ti}^{3+}$ was required in case of sulfate reduction (Table III). (2) There was little or no reduction of S-compounds by dissolution of the other metals ( 8 kinds) in acid (Table IV). (3) In the presence of $\mathrm{K}_{2} \mathrm{SO}_{4}$ equivalent to $1 \mathrm{mg} \mathrm{S}$, the max. rate of decomposition (about $30 \%$ ) was obtained by the combination of $5 \mathrm{~g} \mathrm{Ti}$, $150 \mathrm{ml}$ conc. $\mathrm{HCl}$ and $50 \mathrm{ml} \mathrm{H}_{2} \mathrm{O}$ (Table $\mathrm{V}$ and VI). (4) $\mathrm{SO}_{2}$ was formed by heating $\mathrm{Ti}$ with conc. $\mathrm{H}_{2} \mathrm{SO}_{4}$ while $\mathrm{H}_{2} \mathrm{~S}$ was formed with dil. $\mathrm{H}_{2} \mathrm{SO}_{4}$.

(Received June 7, 1961)

\title{
酸素ボンブ法によるポリエチレン灰分の調製ならびに 鉄, アルミニウムおよびチタンの比色定量
}

\author{
藤原 鎮男， 梄崎 久武*
}

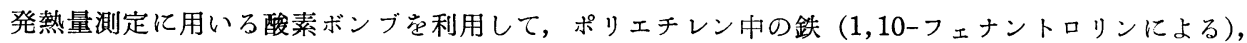
アルミニウム（スチルバゾによる）执よびチタン（タイロンによる）の比色定量を抏てなった。ての方 法の要点は, 酸素のなかに微量に含まれる窒素の酸化生成物によって, 試料が簡単に試料溶液にかえら れることであって，高圧ないし中圧法ポリエチレンなど，試料の種類にかかわりなく，分析するてとが できる．分析の結果，高圧および中圧法ポリエチレンでは鉄がやや多く，アルミニウムおよびチタンは 非常に少ない。低圧法では，どの試料についても鉄はほぼ一定であり，アルミニウムとチタンはそれよ りも多く，しかも両者の割合はほぼ同じ程度である.とれらの元素は灰分の多いものに多いが，敩密に は両者の相関は得られない.
\end{abstract}

\section{1 緒可}

前報1に新いて，著者らはポリエチレン中の灰分の定 量ならびにその定性分光分析について報告したが，今回 は酸素ボンブを用いることによって，鉄，アルミニウム およびチタンの比色定量をおこなったので，その操作な らびに結果について報告する.

高分子の分析について顧みるに，従来，その主成分の 分析については，たとえば赤外線吸収スペクトル， $\mathrm{X}$ 線 回折，核磁気共鳴吸収法などの分析機器を駆使して，多 くの研究がおこなわれており2)，また微量成分について も，主として有機成分については質量分析，ポーラログ ラフ, ガスクロマトグラフ, 紫外線吸収スペクトル法な どによって多くの研究がなされているが，特に無機成分

* 東京大学理学部化学教室 : 東京都文京区本富士町
の分析については，あまりおこなわれていない.したが って, 高分子中の微量無機成分の研究は，まずその分析 法を確立し, さらに反応機構の解明, 品質の改善などに 進むべきもので，重要な意義を有するものと考えられ る.

従来の研究について主なものをあげると, Anduze ${ }^{3)}$ は Parr 式酸素ボンブを用いてポリエチレンを灰化し， その兏分を少量の硫酸水素カリウムとともに融解し，七 酸ジコニウムを担体としてチタンを分離し, 過酸化水 素法によって，チタンの定量をおこなっている.

Fratkina4) は, 低圧法ポリエチレンを炭素末および酸 化銅と混合することにより，アルミニウム $(2660.39 \AA)$ およびチタン $(2646.64 \AA)$ の定量分光分析をおこなって いる. Bolleter ${ }^{5)}$ は，(1) 試料を少量の硫酸カリウムと 硝酸カリウムの混合物 $(3: 1)$ とともに燃焼させる乾式 